\title{
Spectre of AIDS haunts reports of sick cows
}

London. Government officials in Britain were last week playing down reports of a 'mystery illness' that has swept through a Cheshire dairy farm and has been linked to a possible infection with bovine immunodeficiency virus BIV.

The illness was reported in the Independent on Sunday newspaper as "the first case of bovine AIDS in Britain". The report drew the attention of both local and national newspapers to the plight of farmer Tim Blything, whose 50-strong herd of cows in Kelsall, Cheshire, appear to be suffering from a wide-ranging clinical spectrum including nerve degeneration, weight loss, mouth ulcers and respiratory infections.

So far, two of eight cows have tested positive for antibodies to BIV, by three methods - western blotting, immunofluorescence and ELISA (enzyme-linked immunosorbent assay) - and others have shown positive results on one or two tests.

Despite attempts by government officials to minimize the significance of reports linking the illness to the clinical picture associated with AIDS in humans, local companies are refusing to handle meat from the herd or to allow milk to be used for pig-feed.

The Ministry of Agriculture, Fisheries and Food (MAFF) is monitoring the herd. But it says that there are no plans to alert other farmers, or to conduct a national sur-

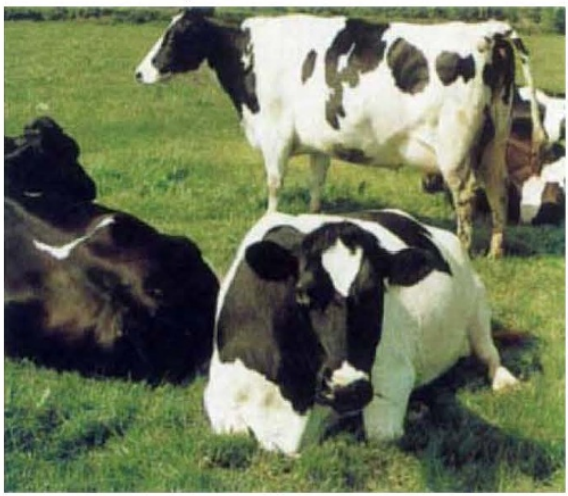

Under threat?

vey of BIV infection in Britain's 11.5 million cattle, as it is not considered to be a notifiable disease, or a threat to human health.

BIV was first isolated in the United States in 1969 from a cow suffering from lymphoma, itself subsequently found to be

\section{BST enters battle for consumers}

Washington. As the biotechnology industry's first food product - milk from cows treated with bovine somatotropin (BST) enters the US market, the battle is on between the food industry and genetic engineering activists on both sides of the Atlantic for the trust of US consumers. Two weeks ago, Monsanto Co. began selling the genetically engineered BST after a 90-day moratorium imposed by the US Congress. Activists responded by dumping milk in the streets, defacing dairy billboards, initiating a boycott and asking local school districts not to give children milk from dairies that used the hormone.

Jeremy Rifkin, an opponent of biotechnology, filed a lawsuit against the US Food and Drug Administration (FDA) for approving the drug. Consumers, restaurateurs and dairy farmers have joined the suit, arguing that the agency failed to consider fully the safety of the drug, and should have ordered special labelling on milk products.

Monsanto, which is based in St Louis, Missouri, has been targeting dairies with mail shots, information packs and meetings in dairy regions. Bob Powell, product manager for the drug, trade-named Posilac, said sales have exceeded Monsanto's expectations, and estimates that one-tenth of US dairy cows will be under treatment by the end of the year.

But many dairy cooperatives and milk processors oppose the drug and have told grocers they will not be supplying milk from cows treated with the hormone. As many as 80 per cent of milk processors in California, the highest-producing dairy state, are said to have either required or asked their suppliers not to use the treatment.

Several have begun printing labels that inform consumers they are not using the drug. The FDA has reacted to the controversy by publishing interim labelling guidelines that allow companies to point out that their milk comes from cows that have not been treated with the hormone - but requires them to provide a context for their remarks, such as giving the reasons why the company had decided against its use.

The FDA says that the hormone is safe for cows and that its presence in milk will not hurt humans. But it is also requiring Monsanto to print labels alerting farmers to increased udder infections and other health problems requiring medication. (Consumer activists fear that such medication may result in antibiotic residue in milk.)

Meanwhile, a survey of UK supermarkets has revealed that many of the major chains would not sell milk from cows treated with BST, even if they were permitted to do so. In member countries of the European Union, the drug is still subject to a moratorium on its use, although this could be challenged in April when the new General Agreement on Tariffs and Trade (GATT) is ratified. due to another virus. But BIV was not known as an immunodeficiency virus until the mid$1980 \mathrm{~s}$, when it was found to be one of a group of animal lentiviruses with homology to the human immunodeficiency virus HIV.

Although BIV is not associated with any particular clinical pathology, all the other viruses in this group are serious pathogens that can lead to a progressive and fatal wasting disease in their host animals. According to Joe Brownlie, of the Institute of Animal Health in Compton, Berkshire, whose team is performing tests on the Cheshire herd on behalf of MAFF, these include goats, sheep and cats.

Brownlie says he is keen for MAFF to conduct a national screening survey. "We need to know what the position is," he says.

Andrew Leigh-Brown of the Centre for HIV Research at the University of Edinburgh says that BIV has been around "for thousands if not millions of years". BIV is equally distantly related to other viruses in the ruminant lentivirus group - including caprine arthritis and encephalitis virus, equine infectious anaemia virus, feline immunodeficiency virus - and from HIV, with 25 per cent difference in protein sequence for the reverse transcriptase enzyme common to each virus.

By comparison, the non-human primate retroviruses, simian immunodeficiency virus and African green monkey virus, are more closely related to HIV, with only 11 per cent difference.

Experimentally, BIV has been found to induce only a transient fever and swollen lymph nodes. Natural infection is found worldwide; it has been detected in Australia, New Zealand, the United States and Europe and has not so far prevented human consumption.

Brownlie says he is keeping an open mind on whether the condition affecting the Cheshire herd is due to BIV or another infectious agent, and warns that no study has been conducted for long enough to rule out a true threat to animal health. "I'm unhappy when I hear that all animals infected with BIV do not get disease," he says. "We shouldn't be too dismissive of it all - we just need a proper scientific investigation."

But he says that he does not expect BIV to pose any risk to humans, particularly as it is unable to grow in human cell culture, and has failed to cause seroconversion following two 'needle-stick' injuries in the United States.

Although the precise prevalence of BIV infection in the United Kingdom is not known, it is probably low, according to Ian McConnell, professor of veterinary science at the University of Cambridge. Nor is there any evidence that any of the ruminant lentiviruses cause disease in humans, he says.

Julie Clayton 